\title{
Modeling of plant adaptation to climatic drought induced water deficit
}

\author{
László HuZSVAI ${ }^{1}$ \& Kálmán RAJKAI ${ }^{2}$
}

${ }^{1}$ Centre for Agricultural Sciences and Engineering, University of Debrecen, 4032

Böszörményi út 138. Debrecen, - tel.: ++361-52-508-444, fax: ++361-52-413-385, email:huzsvai@agr.unideb.hu

${ }^{2}$ Research Institute for Soil Science and Agricultural Chemistry of the Hungarian Academy of Sciences, 1022 Herman O. u. 15,Budapest, Hungary; e-mail: krajkai@rissac.hu

\begin{abstract}
Soil moisture flux to root surface is considered the main determining factor of the transpiration intensity of plants. This assumption is valid not only in optimal plant physiological conditions without any physical barrier for the evaporation from the leaves, but in climatic drought as well, when high usable soil water amount cannot supply the evapo-transpiration intensity of plant. A new algorithm we built up describing the plant adaptation in climatic drought when stoma's closure and reduction of plant's potential evapo-transpiration (PET) starts. The adaptation algorithm of Doorenbos et al. (1978) is developed further defining that soil moisture content initiating the stomata's closure. The critical soil moisture content is varying according to the PET, and drought tolerance of plant. If soil moisture content is less than the critical one, the plant evapo-transpiration (ET) can be highly different in the drought tolerance plant groups. The new drought tolerance algorithm is applied to maize field plots on chernozem soil of the experimental station of the Debrecen University, in East
\end{abstract}


Hungary. Simulated soil water storages are compared to measured ones of a field plot treatment in five consecutive years. The soil moisture content profiles are measured with a BR-150 capacitance probe (Andrén et al. 1991). Differences between measured and simulated soil water storages are not significant in 2003. Simulations indicate low soil water storages in autumn of 2006, and in the first half of 2007 predicting the low maize production realized in 2007. The new plant adaptation algorithm can be used for a climate and soil moisture content sensitive irrigation control as well. The maize production is an illustrative biohydrological example of water flow through the soilplant-atmosphere continuum.

Keywords: Climatic drought, plant water deficit, drought adaptation, crop model

\section{Introduction}

Modeling has become a widely used research tool beside laboratory and field experiments. Agronomic and climatic factors affect soil hydrology both directly and indirectly. Knowledge formalized mathematically in models is successfully used in university education and advisory practice. Great variety of models is applied for different purposes such as planning of agro-technical actions, forecasting of environmental effects, predicting of crop production, demonstrating of environment friendly management, and of decision-making generally.

Extent of crop yield is determined basically by the amount of available water beside the photo-synthetically active energy and air temperature. This is why exact water flow sub-model is needed in crop models for describing processes in the soilplant- atmosphere system. Variety of such water flow models is high, since plant growth itself has many different effects coupled to hydro-physical properties of soils (e.g. 
Farkas et al. 2000). Parameters of soil water flow determined on soil samples involve effects of organic matter amount (Nemes et al. 2005). Hydrophobic nature of soil organic substances is discovered recently causing delayed and reduced infiltration of water to the soil matrix (e.g. Orfanus et al. 2008).

The widely used crop model CERES (Jones \& Kiniry 1986) was used for Hungarian case studies. However, that model calculates extreme high potential evapotranspiration (ETp), and coupled soil water consumption of maize crop. Using the CERES model the maize crop may meet the lack of usable soil water even in the early development phase. If water deficiency occurs in time of grain formation crop loss is resulted. This happens since the model algorithms don't take the extremely low relative air humidity (i.e. atmospheric drought) into consideration.

Generally crop growth models consider the soil moisture flux to be the main factor determining the transpiration intensity of plants. This assumption is valid in case of optimal plant physiological conditions without any physical water evaporation constraints from leaves. Complexity of water flow models is widely ranging from the 'simple water supply balance' type to laminar Darcy type generalized for the unsaturated flow described by the Richards' equation (e.g. Jansson \& Karlberg 2001). In the capacitive model the amount of water in soil is changing by addition of precipitation, capillary rise, irrigation and subtraction of evaporation, transpiration, and deep drainage of plant usable water (e.g. Bossel 1985). In rather complex deterministic mechanistic models as the Coupled heat and mass transfer model (Jansson and Karlberg 2001) or CERES (Hanks \& Ritchie 1984) the soil is divided into several layers. For each soil layer the hydraulic parameters have to be given. In both type of models transpiration intensity or plant water requirement depends on the development stage of 
plant. Number of model parameters is different depending on the model's complexity. According to minimum law the slowest flow process determines the water flow intensity in the soil-plant-atmosphere pathway. The highest probability of limiting water availability or too slow moisture transport occurs in the soil. In case of climatic drought the water flow in plant slows down, since intensity of water uptake from soil drops below of the evaporation from the leaves. For reducing the high intensity water loss plants are closing their stomas in spite of the existence of plenty plant available water in the soil. In such situation dry matters building up of the plant is decreasing due to water deficiency. However, with this protecting reaction plant can survive the period of water deficiency, and secure grain formation. New model algorithms describing the plant adaptation to climatic drought will be presented and demonstrated with simulations in this paper.

\section{Material and method}

Crop production data of the experimental station of the Debrecen University are used as reference for model's simulations. The location of the experimental station is $47^{\circ} 50^{\prime}$ $46^{\prime \prime}$ in the North latitude, and $21^{\circ} 44^{\prime} 66^{\prime \prime}$ longitude at $131 \mathrm{~m}$ above the Baltic see. Experimental data have been available since 1984. Moisture dynamics of the experimental plots are monitored in access tubes with the BR-150 moisture meter (Andrén et al. 1991).

Soil characteristics of the experimental plots are given in Table 1. The soil type of the experimental station is mollisol formed on loess by FAO classification. The lime is washed out from the upper $120 \mathrm{~cm}$ of the soil. Consequently the $\mathrm{pH}_{\mathrm{H} 2 \mathrm{O}}$ is slightly acidic in the upper $40 \mathrm{~cm}$ and is becoming neutral at the $120 \mathrm{~cm}$ depth (Table 1). The 
$\mathrm{CaCO}_{3}$ content of the soil is changing conversely to $\mathrm{pH}$. Average humus content of the soil is $2.4 \%$, and the nutrient supplying potential $\left(\mathrm{P}_{2} \mathrm{O}_{5}\right.$ is $164 \mathrm{ppm}$, and $\mathrm{K}_{2} \mathrm{O}$ is 318 ppm) is good.

Field capacity of the mollisol in the root zone in the experiment occurred to be at $0.30 \mathrm{~m}^{3} \mathrm{~m}^{-3}$ moisture content, and at $0.12 \mathrm{~m}^{3} \mathrm{~m}^{-3}$ for the wilting point.

Table 1. Soil characteristics of the representative soil profile in the experimental fields.

\begin{tabular}{cccccc}
\hline $\begin{array}{c}\text { Depth of } \\
\text { soil layers } \\
(\mathrm{cm})\end{array}$ & $\begin{array}{c}\text { Bulk density } \\
\left(\mathrm{Mg} \mathrm{m}^{-3}\right)\end{array}$ & $\begin{array}{c}\text { Wilting point } \\
\left(\mathrm{m}^{3} \mathrm{~m}^{-3}\right)\end{array}$ & $\begin{array}{c}\text { Field } \\
\text { capacity } \\
\left(\mathrm{m}^{3} \mathrm{~m}^{-3}\right)\end{array}$ & $\begin{array}{c}\mathrm{OC} \\
\%\end{array}$ & $\mathrm{pH}_{\mathrm{H}_{2} \mathrm{O}}$ \\
\hline 5 & 1.38 & 13.0 & 31.4 & 1.99 & 6.5 \\
15 & 1.42 & 13.0 & 32.2 & 1.99 & 6.5 \\
30 & 1.45 & 13.0 & 32.8 & 1.95 & 6.7 \\
45 & 1.29 & 12.9 & 29.5 & 2.00 & 7.0 \\
60 & 1.24 & 12.7 & 28.5 & 1.40 & 8.0 \\
90 & 1.25 & 10.8 & 28.7 & 1.05 & 8.1 \\
120 & 1.20 & 10.2 & 27.7 & 0.57 & 8.1 \\
\hline
\end{tabular}

Plant adaptation algorithm of Doorenbos et al. (1978) gives empirical soil water depletion ratios $(p)$ for drought tolerance plant groups at PET values (Table 2). The formula of van Diepen et al. (1988) describes the relationship between different soil moisture contents and $p$ ratios:

$$
\Theta_{w s}=(1-p)\left(\Theta_{f c}-\Theta_{w p}\right)+\Theta_{w p}
$$

where, $\Theta_{w s} \quad$ : Critical soil moisture content $\left(\mathrm{m}^{3} \mathrm{~m}^{-3}\right)$

$$
\begin{aligned}
& p \\
& \Theta_{f c}: \text { Soil water depletion fraction as a function of the PET } \\
& \Theta_{w p} \quad: \text { Soil moisture content at field capacity }\left(\mathrm{m}^{3} \mathrm{~m}^{-3}\right)
\end{aligned}
$$


Table 2. Soil water depletion $(p)$ at potential evapo-transpiration (PET) values and for closed canopy drought tolerance plant groups (1-5) (Doorenbos et al. 1978).

\begin{tabular}{|c|c|c|c|c|c|c|c|}
\hline & \multicolumn{7}{|c|}{$\operatorname{PET}\left(\right.$ mmday $\left.^{-1}\right)$} \\
\hline$\ddot{\Xi}$ & 2 & 3 & 4 & 5 & 6 & 7 & 8 \\
\hline $\mathrm{a}$ & 0.45 & 0.38 & 0.30 & 0.25 & 0.23 & 0.20 & 0.18 \\
\hline 500 & 0.60 & 0.50 & 0.43 & 0.35 & 0.30 & 0.28 & 0.25 \\
\hline 3 & 0.75 & 0.65 & 0.55 & 0.45 & 0.40 & 0.38 & 0.33 \\
\hline$\overline{\frac{\pi}{0}} 4$ & 0.85 & 0.75 & 0.65 & 0.55 & 0.50 & 0.48 & 0.43 \\
\hline 5 & 0.92 & 0.85 & 0.75 & 0.65 & 0.60 & 0.55 & 0.50 \\
\hline
\end{tabular}

Crops in the drought tolerance groups:

1 Leaf vegetables, strawberry

2 Clover, carrot, early tobacco

3 Grape, pea, potato

4 Citrus, peanut, pineapple

5 Olive, sunflower, sorghum, soybean, sugarcane
1-2 Cabbage, onion

2-3 Banana, pepper

3-4 Bean, sunflower, tomato, water melon, grass

4-5 Alfalfa cotton, tobacco, cassava, sweet potato, grains

When the soil moisture content is lower than the critical one in Eq.(1) the plant

ET is reduced. For that reduction we use the formula of van Diepen et al. (1988):

$$
R_{w s}=\frac{\Theta_{t}-\Theta_{w p}}{\Theta_{w s}-\Theta_{w p}}
$$

where, $R_{w s} \quad$ : Reduction factor for transpiration in case of water shortage;

$\Theta_{t} \quad:$ Actual soil moisture content $\left(\mathrm{m}^{3} \mathrm{~m}^{-3}\right)$

$\Theta_{w p} \quad$ : Soil moisture content at wilting point $\left(\mathrm{m}^{3} \mathrm{~m}^{-3}\right)$

$\Theta_{w s} \quad$ : Critical soil moisture content $\left(\mathrm{m}^{3} \mathrm{~m}^{-3}\right)$

For determining of PET, we adopted the algorithm of Szász (1977): 


$$
\left.P E T=\beta 0,0095(T+21)^{2}\right)(1-R)^{2 / 3} f(v)
$$

where, $\beta \quad$ : Oasis effect

$T \quad$ : Average air temperature, $2 \mathrm{~m}\left({ }^{\circ} \mathrm{C}\right)$

$R \quad$ : Relative humidity (e/E)

$f(v) \quad$ : Function of wind speed, $(v)$ wind speed $\left(\mathrm{m} \mathrm{s}^{-1}\right)$

Plant adaptation functions of the new model are built into Excel menu options. The water transport equations are parameterized according to the van Genuchten soil water retention function. For numerical solution of water and heat transport equations the Thomas algorithm is applied (Remson et al. 1971). Both these algorithms are stand alone and can be run separately. When neither water retention, nor conductivity data of the soil or soil layers are available, pedotransfer functions can be used (Rajkai et al. 2004). (For further details, see 'Help' option of the new model.)

Evaporation of the bare soil depends on the PET and the actual soil moisture content. Soil evaporation may occur from full saturation to hygroscopic value; which is equal to one-fourth of the wilting point in the model (Kreybig 1951). At full saturation, evaporation is equal to PET; between saturation and wilting point, evaporation decreases exponentially. Language of the model is Visual Basic (1987-2001). Algorithms from different sources are arranged in uniform dimension, and framed into MS Excel (2002).

Water storage of soil is calculated from the cumulated soil moisture contents read by the BR-150 capacitance probe (Andrén et al. 1991) in $10 \mathrm{~cm}$ intervals down to $120 \mathrm{~cm}$.

For monitoring the air temperature Vaisala thermometers were used at $2 \mathrm{~m}$ height. Experimental and weather data recorded from 2003 to 2007 are used for 
modeling maize transpiration with the new model containing plant's drought tolerance algorithm. Model runs for maize will be used only.

\section{Results and discussions}

The newly built crop model is a synthesis of selected algorithms of the CERES (Jones and Kiniry 1986), Wofost (e.g. 1988), Daisy (1990), and Bossel (1985) models, and the Eq. (1) to Eq.(3) for taking into account of soil moisture contents and plant drought tolerance.

In order to establish the critical soil moisture contents of the chernozem soil for the drought tolerance plant groups we used the p data of Table 2 and Eq.(1) and the soil parameters $\left(\theta_{\mathrm{fc}}\right.$ and $\left.\theta_{\mathrm{wp}}\right)$ in Table 1 . The calculated the critical soil moisture content values are given in Table 3 . The critical soil moisture content for the maize crop $\left(3^{\text {th }}\right.$ drought tolerance group) is varying between 0.17 and $0.24 \mathrm{~m}^{3} \mathrm{~m}^{-3}$.

Table 3. Calculated critical soil moisture content values of chernozem soil $\left(\mathrm{m}^{3} \mathrm{~m}^{-3}\right)$

\begin{tabular}{|c|c|c|c|c|c|c|c|}
\hline & \multicolumn{7}{|c|}{$\operatorname{PET}\left(\mathrm{mm} \mathrm{day}^{-1}\right)$} \\
\hline$\vec{\Xi}$ & 2 & 3 & 4 & 5 & 6 & 7 & 8 \\
\hline 21 & 0.22 & 0.24 & 0.25 & 0.26 & 0.26 & 0.27 & 0.27 \\
\hline 5040 & 0.19 & 0.21 & 0.23 & 0.24 & 0.25 & 0.25 & 0.26 \\
\hline 3 & 0.17 & 0.19 & 0.20 & 0.22 & 0.23 & 0.24 & 0.24 \\
\hline$\frac{\pi}{4}$ & 0.15 & 0.17 & 0.19 & 0.20 & 0.21 & 0.22 & 0.23 \\
\hline 5 & 0.13 & 0.15 & 0.17 & 0.18 & 0.19 & 0.20 & 0.21 \\
\hline
\end{tabular}

Mean of the critical soil moisture contents in the PET range is $0.21 \mathrm{~m}^{3} \mathrm{~m}^{-3}$ for the chernozem soil (Table 3). This is just exactly the optimal moisture content of the soil given as $70 \%$ of the field capacity $\left(0.30 \mathrm{~m}^{3} \mathrm{~m}^{-3}\right)$ by plant production experts in Hungary (Nyíri 1993). 
On critical soil moisture contents (Table 3) the actual transpiration of closed canopy maize fields and plants of the other drought tolerance groups on chernozem soil are calculated using Eq.(2), and shown in Table 4.

We can read from Table 4 that a drought sensitive (1) maize variety may evapotranspirates 3,3 1 water $\mathrm{m}^{-2}$ at $6 \mathrm{~mm}$ PET. The ET goes up to $5,31 \cdot \mathrm{m}^{-2}$ in case of drought tolerant (4-5) maize varieties.

Table 4. Actual transpiration $\left(\mathrm{mmday}^{-1}\right)$ at the critical soil moisture contents of the chernozem soil..

\begin{tabular}{|c|c|c|c|c|c|c|c|c|}
\hline \multirow{2}{*}{\multicolumn{2}{|c|}{$\begin{array}{l}\ddot{\Xi} \\
\tilde{\Xi}\end{array}$}} & \multicolumn{7}{|c|}{ PET $\left(\right.$ mmday $\left.^{-1}\right)$} \\
\hline & & 2 & 3 & 4 & 5 & 6 & 7 & 8 \\
\hline$\stackrel{0}{\overrightarrow{0}} \vec{\Xi}$ & 1 & 1.58 & 2.03 & 2.46 & 2.88 & 3.30 & 3.73 & 4.18 \\
\hline$\stackrel{\pi}{2}$ & 2 & 1.76 & 2.61 & 3.00 & 3.39 & 3.77 & 4.16 & 4.56 \\
\hline 0 & 3 & 1.76 & 2.63 & 3.51 & 4.08 & 4.41 & 4.74 & 5.09 \\
\hline & 4 & 1.76 & 2.63 & 3.51 & 4.39 & 5.27 & 5.61 & 5.95 \\
\hline & 5 & 1.76 & 2.63 & 3.51 & 4.39 & 5.27 & 6.14 & 7.02 \\
\hline
\end{tabular}

Transpiration intensity of different drought tolerant plants or plant varieties is significantly different. ET of maize in the $3^{\text {rd }}$ drought tolerance group is 1.76 liter water $\mathrm{m}^{-2}$ at 2 mmday $^{-1}$ PET, which is $86 \%$ of the potential amount. Actual transpiration of maize however, decreases to $74 \%$, and $64 \%$ of the potential value at 6 and 8 mmday $^{-1}$ PET, consecutively. Decreasing ET and increasing PET demonstrates effectivity of the new algorithm of the plant growth model taking into consideration the limited availability of soil moisture.

Simulating the maize growth and yield in five consecutive years from 2003 to 2007 with the plant adaptation algorithm to climatic drought we estimated time 
variation of the water storage of the $1.2 \mathrm{~m}$ deep soil profile (Fig. 1). The difference between measured and simulated soil water storages is not significant in 2003 . However, model estimates are lower than field measurements in the flowering period of 2004 and 2006 years. Significance of the deviation in the flowering period is high since the water consumption of maize in that period is the highest. Unfortunately it is not clear whether the model description or the soil moisture measuring instrument (BR-150) or technique (one access tube in the plot) is responsible for the experienced deviations. The slow redistribution of water in soil can be a possible reason of differences, because in reality, water redistribution happens at a lower speed than forecasted by the model.

It is, however, rather evident that the low soil water storage values in the autumn of 2006 and the first half of 2007 (Fig. 1) are responsible for the low yield production of maize in 2007.

With the increase of temperature and vapor deficiency of air from winter to summer the PET values are increasing (not shown). Higher PET generates increased water consumption of maize. Model estimated potential ET of maize increases almost exponentially from germination (not shown).

Actual ET of maize is almost identical with PET when water supply from soil and by precipitation allows it, but they significantly differ in dry periods e.g. in 2007 ET of maize can be half of the PET, which may generate a significant crop loss, as it was the case in 2007. In that year average maize yield was the lowest $\left(4.8 \mathrm{tha}^{-1}\right)$ in the whole Hajdú-Bihar County. The other low yield $\left(5,5\right.$ tha $\left.^{-1}\right)$ of maize was in 2003 when actual ET and PET difference isn't striking but constant with an abrupt difference in the most sensitive flowering time. Contrary the actual ETs were almost identical with PETs (4 and 5 mmday $\left.^{-1}\right)$ and county average maize yields (7.6-8.2 tha $\left.{ }^{-1}\right)$ were similar in 2004- 
2006 years. In order to get a more complex view on soil water balance, we composed the time-related soil water storages (see Figure 1.).

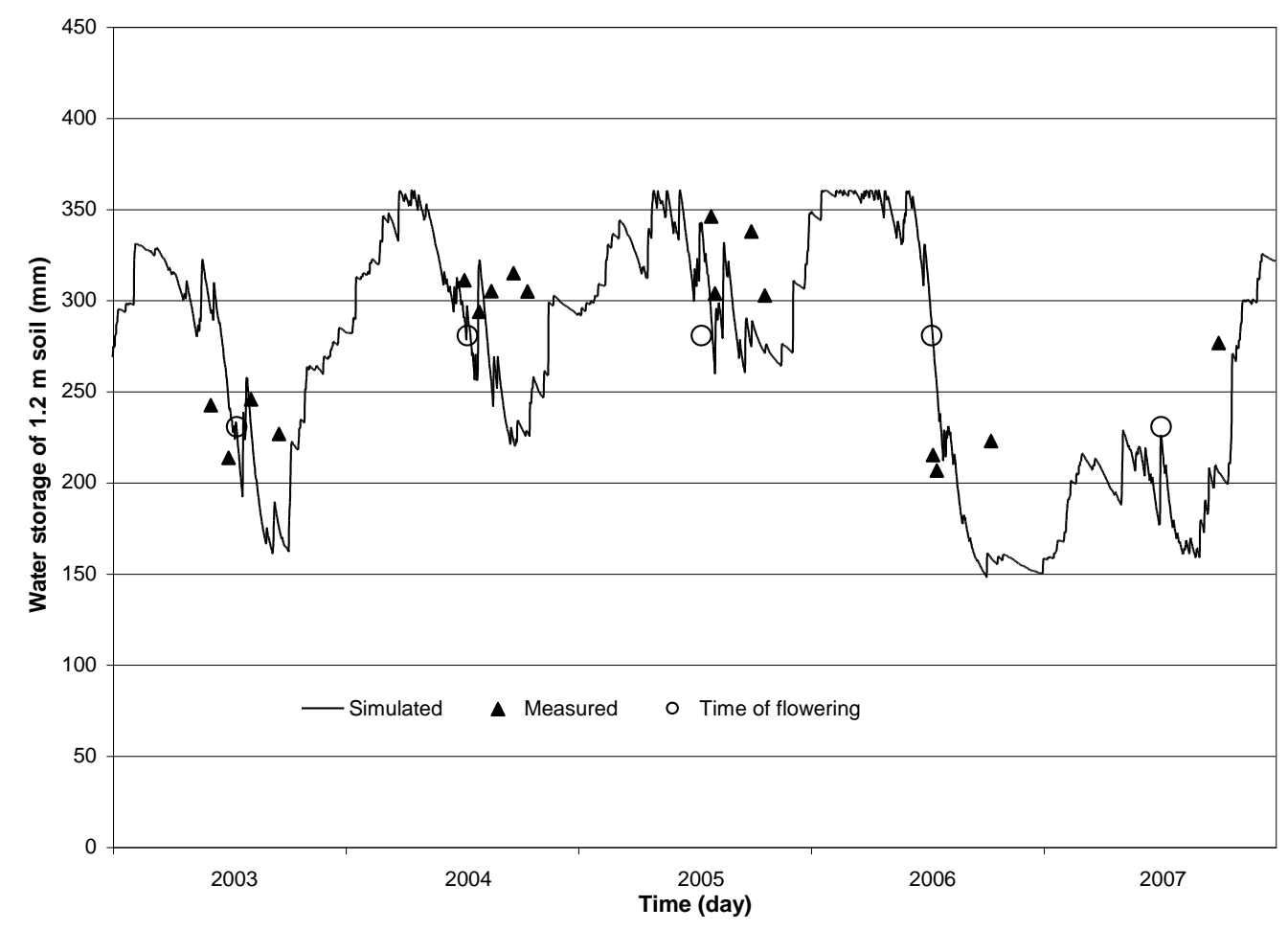

Fig. 1. Simulated and measured soil water storages of the upper $1,2 \mathrm{~m}$ soil profile between 2003 and 2007.

Evaporated water amount increases from $0.2-0.3$ up to $2-2.21 / \mathrm{m}^{2}$ of bare soil surface from January to April. However, soil evaporation is practically negligible in the close canopy maize field. In general, it can be established and concluded that water flow processes and intensities within and from the soil are influenced, triggered or at least moderated by plants.

Soil water flow plays an important role in biohydrological processes (Rajkai 2008). The method presented in this paper, which accounts for plant adaptation in modeling changes in soil water storage in relation with time, may further define insights on biohydrological processes. 


\section{Acknowledgements}

The Hungarian Research Found project CK 77503 financial supports are greatly acknowledges.

\section{References}

Andrén O., Rajkai K. \& Kätterer T. 1991. A non-destructive technique for studies of root distribution in relation to soil moisture. Agriculture Ecosystems \& Environment 34: 269-278.

Bossel H. 1985. Umweltdynamik te-wi. Verlag GmbH, München, 466 pp.

van Diepen C.A., Rappoldt C., Wolf J. \& Van Keulen H. 1988. Crop growth simulation model WOFOST. Documentation version 4.1, Centre for World Food Studies, Wageningen, The Netherlands. 299 pp.

Doorenbos J. \& Kassam A.H. 1979. Yield Response to Water. F.A.O., Rome, 193 pp.

Doorenbos J., Kassam A.H., Bentvelder C. \& Uittenbogaard G. 1978. Yield Response to Water. U.N. Economic Commission West. Asia, Rome, Italy.

Farkas, Cs., Gyuricza Cs., László P. \& Birkás M. 2000: Study of the influence of soil tillage on soil water regime, pp. 251-257. In. Horn R., van den Akker J.J.H. \& J. Avidsson (eds), Subsoil Compaction. Advances in Geoecology 32., Catena Verlag, Reiskirchen.

Hanks J. \& Ritchie J.T. (eds) 1984. Modelling Plant and Soil Systems. Agronomy series 31. ASA, CSSA, SSSA Publ. Madison, Wisconsin, USA.

Hansen S., Jensen H.E., Nielsen N.E. \& Svendsen H. 1990. DAISY - Soil Plant Atmosphere System Model. NPO-Research Report No. A 10. The National Agency 
of Environmental Protection Copenhagen, Denmark.

Jansson P-E. \& Karlberg L. 2001. Coupled heat and mass transfer model for soil-plantatmosphere systems. Dept. of Land and Water Resour. Engineering, Royal Inst. of Technology, Stockholm. 321 pp.

Jones C.A. \& Kiniry J.R. (eds) 1986. CERES-Maize. A Simulation Model of Maize Growth and Development. Texas A $\square$ M University Press, College Station.

Kreybig L. 1951. Water and heat management of soils. (A talajok hö- és vízgazdálkodása.). Mezőgazdasági Kiadó, Budapest.

Nyiri L. 1993. Földmüveléstan. Mezőgazda Kiadó, Budapest.

Microsoft Visual Basic 6.3 1987-2001 Microsoft Corp.

Orfánus T., Bedrna Z., Lichner L., Hallett P.D., Kňava K . \& Sebíň M. 2008. Spatial variability of water repellency in pine forest soil. Soil Water Res. 3(Special Issue 1): $\mathrm{S} 123-\mathrm{S} 129$.

Rajkai K., Szász G. \& Huzsvai L. 2004. Agro-ecological models. 103 pp. (in Hungarian)

Rajkai K. 2008. Soil role in bioclimatology. Soil Water Res. 3(Special Issue 1): S23S34.

Remson I., Hornberger G.M. \& Molz F.J., 1971. Numerical methods in subsurface hydrology. Wiley, New York, p. 389.

Szász G. 1977. Agrometeorology. In the University Notebook Series. Debrecen University, Debrecen. 230 pp. (in Hungarian) 